\title{
EVOLUTIONARY STAGES OF DEVELOPMENT OF INTEGRATION FORMS OF THE MONOPOLIZATION PROCESS
}

\author{
Nataliya Rudkovska \\ Ivan Franko National University of Lviv, \\ 79008 Lviv, Prospekt Svobody, 18 \\ e-mail:nataliya.rudkovska@Inu.edu.ua
}

\begin{abstract}
The primary task of Economics, as the science of rational allocated of limited resources, is not always fulfilled in today's globalized world. Human irrationality and opportunism are forcing economic agents to invent new ways to maximize their profits, accompanied by a deterioration in the welfare of others. A regular consequence of this desire is the deepening and aggravation of monopolization processes that was occured during almost all periods of world economic development. Seizing power over limited resources to control the market was as common in Medieval Europe at natural fairs as it is today in the High-Tech Market. However, due to the growing opportunities for the scale of influence of entrepreneurs that have gone far beyond nation-states, market transaction processes require more complex market structures. Since technology and innovation have made possible the type of economic systems that we observe today in developed economies, its revolutionary changes should be linked to the evolutionary changes of market integration forms in monopolization processes.

The classical interpretation of the monopoly as the sole trader in the market does not deny the possibility of its representation by the association of several or even many economic entities deprived of economic independence as a result of acquisitions or mergers, or operating in the market in a collude. Monopoly power in the market means that production resources will not be used rationally, and consumer needs will not be fully met.

The importance of studying the conditions and factors of integration forms that can contribute to monopolization processes in industry markets led to the writing of this article. The paper highlights the stages of evolution of integration forms of the monopolization process through the prism of the Technological Revolutions, as a favorable environment for its development. Keywords: monopoly, monopolization, integration forms of the monopolization process, trust, holding, TNCs.
\end{abstract}

Formulation of the problem. Abstract theoretical models are often limited in finding the way of resolving market failures and analyzing market prospects. Therefore it is important to investigate examples of real economic models, in particular, how it was operating in different stages of historical realities. Considering on few cases observation ideal types of market structures (perfect competition and pure monopoly) in research of monopolization

(C) Nataliya Rudkovska, 2020 
process we should put emphasize on market types where conduct activity integration forms of entities activity because of such market structure can be able to effect threatening preconditions for monopolization of industrial markets.

Due to the significant impact of evolutionary processes on modern trajectory of economic development it is worthily to consider variety of monopoly integration forms that was conducting economic activity in certain stages of history and function on the market today. Consider how it influences on development of the world economy using retrospective analysis.

Analysis of recent research and publications. The works of L. Fedulov, Y. Fedotova, I. Yatskevich, R. Danileychuk, S. Klaus, Zingales L. as well as a number of reports of the World Economic Forum and the publications of leading economic institutions confirm us in the effect that is caused by technological changes on production and structural features industrial markets in the world economy, that intensificate it's concentration level and molopolization what directly influence on consumers. There were researched features of various forms of integration associations, were given it's comparative analysis, are trace the historical conditions of nascence by researchers. Nonetheless systematization of market factors that contributed to the emergence of coordination between economic entities and as a result monopolization of industrial markets at a particular stage of technological development of mankind are stayed out of attention. As we observe today even more radical tendencies for reformation of entities forms, it is important to research experience and evolution of changes in integration processes in markets and to predict the future consequences of monopolization and to envisage the necessary state regulatory policy.

The formulation of the paper's objective. The purpose of the article is to structure stages of nascence and functioning of entrepreneurship integration forms, which resulted monopolization of industries in national economies.

Presentation of the main research material. To conduct a research, firstly it is necessary to outline the concept of economic integration of business entities, emphasizing the characteristics of integration forms of the monopolization process.

I. Yatskevych under economic integration defines "the interaction process of two or more business entities, which leads to approaching, interpenetrate, intertwining of activities, resources and management potential." In her opinion, the main overall goal of business entities integration is increasing the efficiency of the newly created integrated structures that consists in increasing the share of the company in the market, increasing the volume of products and the range of potential consumers, improving the quality of products, etc $[10, p$. 476-477].

Yu. Fedotova clarifications that "an integrated structure is an association formed by two or more economic entities by establishing civil law relations for the purpose of receiving a profit from mutual economic activity and its coordinated due to possibility creation a single centralized governing unit [8, p. 415].

The Commercial Code of Ukraine states that «enterprises have the right to unionize their economic activities on a voluntary basis, if it does not contradict the antitrust law of Ukraine. An association of enterprises is a business organization formed of two or more enterprises in order to coordinate their production, scientific and other activities to solve common economic and social problems» [1].

The integration process reveals itself in the methods of horizontal and vertical integration through acquisitions and mergers. W. Viscuzi, J. Vernon, J. Harrington among the most common methods of integration allocate horizontal, vertical and conglomerate. Horizontal mergers occur in the process of merging competitors operating in the same 
market, thereby increasing market concentration. Vertical is the association of firms that are interconnected by a single technological chain of production processes. All other mergers that do not belong to the characteristics of horizontal or vertical, are classified as the formation of conglomerates - associations of firms not related to each other in either production or marketing processes. At the same time, mergers do not always involve the creation of integration forms and are aimed at combining the capacities of firms, which increases the likelihood of socially beneficial savings due to reduced transaction costs. According to the above scientists, the main goals of integration processes are to expand the range of products, expand market boundaries or enter new markets [2, p. 253].

In world practice, there are various forms of integration, each of that has its own conditions and consequences. L. Fedulova as the main organizational-economic forms distinguishes: large companies with a divisional structure, holding companies, financial and industrial groups, consortiums; contract groups; transnational corporations (TNCs). In her opinion, the presence of a large number of TNCs that operating on the world market characterizes a very high level of its monopolization $[9$, p.16,18].

V. Gorbatov notes that «in the world business practice, 10 main organizational forms of integrated business structures have become widespread: trusts, concerns, conglomerates, financial-industrial groups, cartels, syndicates, pools, consortiums, strategic alliances and associations». [4, p. 7].

R. Danileychuk names the next integrated business structures: corporations, concerns, holdings, financial and industrial groups, TNCs and strategic alliances; clusters as a form of sectoral and territorial integration of business structures; integrated structures of innovative entrepreneurship that implement the integration of science and production [3, p. 221-222].

Domestic legislation defines the following organizational forms of corporate structures: association, corporation, consortium, concern, industrial and financial group, holding [1].

Integration forms are not prohibited by antitrust law, provided that its creation and operation will not significantly increase the level of monopolization in the industry market. We will formulate the circumstances and features that allow us to identify a particular integration association as a potential threat to the competitive environment, and to consider this entity as an integration form of the monopolization process. If its subjects:

- occupy a significant market share and after its integration, market concentration reaches a critical value of 0.18 , according to the Herfindahl-Hirschman index;

- have advantages in production, unique technologies or product;

- operate in an extractive institutional environment, that include administrative barriers entry and exit on the market, excessive state regulation of sectoral markets, nationalization of the economy, corruption, oligarchy, illegal lobbying, unfavorable historical preconditions.

To simplify the analysis, we classify the most common integration forms into two groups, depending on the degree of influence on the monopolization process:

1. Ones that remain independent business entities without losing economic and legal independence, without creating a single center of management, and make joint decisions to achieve certain goals - act on the basis of cooperation (cartel, syndicate, association). Thus, the formation of such associations does not increase market concentration and does not formally mean the operation of a single monopoly.

2. Ones that partially or completely renounce its legal, production and financial independence and become centrally subordinated to the newly created governing body (holding, trust, concern, TNC). Depending on the each production share of the previously 
independently functioning members of the association, the market concentration increases significantly, what is a prerequisite for bringing it closer to the signs of a monopoly market.

In our analysis, we will consider the associations that belong to the second group, because, as a rule, the monopolization process is linked with increased market concentration. However, the growth of economic power of industry market agents as a result of concentration processes is not unequivocal evidence of its monopolization, so it is important to consider the impact of integration forms on the monopolization of the industry market, using other quantitative and qualitative indicators [14].

The holding is defined as a joint-stock parent company that owns controlling stakes in legally independent subsidiaries to exercise control over its operations, but does not take a direct active part in their management. The holding company is established in order to adopt a strategic course of activities of its member companies to improve financial results, direct investments in the most promising areas, establish and coordinate communication and productive personnel policy. In turn, subsidiaries address the tactical issues of its operations.

The most centralized integration entity is a trust, enterprises that became part of it divisions, lose its independence and nobility to make decisions about its activities. The merger of enterprises into a trust can occur either through the inclusion of one enterprise in another, or the formation of a new enterprise. A similar integration is a group in which financial control and certain functions of supply, production and marketing of enterprises are under a single management, but it does not lose its legal independence.

According to the official definition of the United Nations Commission on Trade and Development (UNCTAD), a TNC is an enterprise that unites legal entities of all organizational-legal forms and activities in two or more countries and implement a common policy and overall strategy through one or more decision-making centres [7].

Industrial revolutions generate new technological systems and create a favorable environment for resource accumulation, optimization and expansion of production, that leads to changes in management and requires modified structural and organizational forms of firms and enterprises. The firm, as a key object of Ronald Coase's institutional analysis, emerges, in his view, precisely with the complexity of transactional processes, in order to reduce its value. The need for control over the various structural units of the firm requires a wellcoordinated management staff and significant capital injections to ensure continuous financing not only of current production, but also permanent product improvement and innovation of technological processes.

The monopolization of industrial markets is most fully manifested in the monopolization of capital, where it is involved. Therefore, since the beginning of capital accumulation, starting from the period of the Great Geographical Discoveries, markets have not always demonstrated its competitive conditions, moreover, it is much more pronounced in anticompetitive associations. Understanding the complexity of the accumulation of equity by one firm, helped to unite enterprises for consolidation (concentration of capital). Thus, a «monopolist" was born with a different share of influence of individual owners operating under one «cover».

We propose to single out the stages of the nascence of integration forms of the monopolization process, through the prism of the Industrial Revolutions. Revolution - as an abrupt, radical change, compared with the previous state of development, changes the production capacity, which leads to the evolution of organizational market forms.

Stage I. The Industrial Revolution (2nd half of the 18th - 1st half of the 19th century) transition from agrarian to industrial economy. 
Prior to this stage, the feudal system in society and the colonization of the New World were the main sources of capital, the increase of which was devastating, due to it passed from hand to hand. In return, the Industrial Revolution led to rapid economic growth, unprecedented, as a result of the accumulation of new capital, the source of which was the growth of productivity. At the initial period, the rapid increase in population and favorable institutional environment created wide opportunities for inventions and the beginning of own craft. At the same time, the ideas put forward at that stage by the representatives of classical economics - the importance of competition, creating better and cheaper goods, giving freedom to entrepreneurs, rejecting false negative prejudices associated with technical innovations - had a significant impact.

However, the nature of labor organization changed from handicraft production to a factory-centric model in the period from 1760 to 1850 . The ideas of free competition spread as rapidly as the number of factories, first in England and later throughout Europe. However, the gradual growth of heavy industry and mechanical engineering had led to the identification of strong players in the market. Centralization, concentration of capital and production capacity made the monopoly an integral part of industrial society, which at that time functioned in its classical sense, mainly representing the only entity in the market.

Stage II. The Technological Revolution (2nd half of the 19th century-beginning of the 20th century), which is reflected in changes in production technologies - the replacement of steam energy with electricity, implementation of conveyor processes, the widespread use of petroleum products. The most common form of production is a corporation that focused on standardization and mass production.

The classic example of the development of monopolization capital during this period was the United States of America. Favorable recreational potential, a strong raw material base, developed infrastructure, in particular, the construction of railways, in tandem with an effective state policy of protectionism and the successful application of the Second Industrial Revolution inventions - made a powerful industrial-agricultural country and gave it supremacy. Nevertheless, the economic development of the USA was interrupted by crises of overproduction, accompanied by stagnation, which was the driving force to the concentration of production and centralization of capital.

The most common form of monopoly in the United States of America - trusts, that in 1901 owned 3/4 of all industrial products in the country. This process was began in 1879 . by J. Rockefeller who founded the Standart Oil Trust in the oil industry, that led to the monopolization of $90-95 \%$ of refined oil in the country. Later, the merger of trusts with banking monopolies led to the creation of a financial oligarchy, represented by two leading banking groups: J. Morgan and J. Rockefeller, which united 112 banks, railways, insurance and other companies, and their capital exceeded \$ 22 billion (56\% of the country's share capital) by 1903 [5].

In the USA during 1895 to 1904 was created 42 big corporations that controlled at least $70 \%$ of respective industry markets. It was caused by great merger which threatened American entrepreneurial traditions, that regarded competition as a necessary way to economic growth and prosperity of public welfare, making monopoly unacceptable way of functioning of the market [15].

Trusts have been criticized and their structure has not been effective in all areas of business, in particular, the construction of railways in the UK and the USA required investment while investors who accumulated capital during the industrial construction and development phase wanted to invest it. This contributed to the creation of holding companies as a form of corporate control, first in New Jersey, the USA in 1889. This process of capital 
concentration and market power in the hands of a small number of people monopolized strategically important industry markets.

Stage III. The Digital Revolution (2nd half of the XX century - the first decade of the $X X I$ century) - transition from analog to digital technologies.

Changes in the sectoral structure of the economy were closely linked to changes in the sphere of production, in particular, the use of distributed production. The main characteristic feature of the new industrialization was the shift of efforts from creating a product to the design phase, as well as to the phase of product promotion to the consumer. Computerization of the economy, the widespread use of electronics, computers, and information technology have changed not only production capacity but also management style and human relationships. Corporations began to take on more complex forms, the borders of countries ceased to be a constraint on the expansion of influence, began to create branches in the form of subsidiaries around the world, with headquarters in the founding country.

TNCs, that had began operating in the early XVII century, the greatest dominance in the world market achieved two decades after World War II. In the mid-50s of XX century banks in the world's leading countries begun large-scale investment in industrial stocks, stimulating mergers and fostering capital concentration. Thus, if in 1906 there were 2-3 leading firms with assets of $\$ 500$ million, in 1971 there were 333 such corporations, and TNCs began to control $70-80 \%$ of the world trade outside the centrally planned economies [11].

The ability of TNCs to maximize its monopoly profits and reduce the tax burden is explained by the ability to carry out "transfer pricing". This method allows TNCs to set prices for transfers of goods, services, technology and loans between its branches around the world. Such prices are significantly different from the prices that unrelated firms would have to pay. This is a mechanism that allow to reduce the price in countries where tax rates are high, and increase it in countries with lower tax rates.

Today, in the world are about 60000 of parent TNCs and about 500000 branches. Along with that TNCs had grown to huge size and its annual turnover exceeds the GNP of most countries [13, p. 152].

The threatening fact is that nation-states today are more vulnerable than giant monopolies. Influencing factors that give TNCs a monopoly position in the world market are closely intertwined in identifying its positive and negative sides for public welfare):

- diversification of production process in different countries, taking into account the available resources and potential of its markets (but devastation of the resources of the host countries);

- access to larger capital resources, including long-term loans (but the concentration of capital);

- constant awareness of market conditions and greater access to information (but through spheres of influence, the possibility of disseminating information beneficial to them);

- clear organizational structure (but too large payment packages to management and shareholders).

These features have given TNCs the opportunity to actually establish the "rules of the game" in the world market, making them "monopolists of the XXI century."

Stage IV. Industry 4.0 (have begun in the second decade of the XXI century) - represents the rapid spread of computing, cloud storage, artificial intelligence, and billions of networked devices, that taking production and consumption to the next level.

In 2017, the main topic for discussion at the World Economic Forum (WEF) in Davos was the stage of the current era of innovation, under the influence of which, changing 
industries. A new type of industrial production will be based on so-called big data and its analysis, production automation, augmented reality technologies and the Internet of Things.

The term "Industry 4.0" was originated in 2011 at the Hanover Fair to explain global value added chains. It was introduced by WEF founder Klaus Schwab in his book, The Fourth Industrial Revolution, describes Industry 4.0 as blurring the boundaries between the physical, digital, and biological spheres. The first steps in the world towards a new industrial revolution were cloud technology, the development of methods for collecting and analyzing Big Data, crowdsourcing, biotechnology, unmanned vehicles and medicine based on 3D printing. The cryptocurrency Bitcoin and Blockchain technology have emerged in the world of finance. Klaus Schwab identifies four main effects: rising customer expectations; improving product quality; joint innovations; new forms of organization. According to him, the leaders will be companies that have a unique platform that unites many people [6].

"Smart companies" are replacing large corporations and rent-seeking monopolies. The development of technology allows the delegation of responsibilities to people all over the world, which can lead to the cooperation of promising young people and the creation of their own products that could create competition for global corporations. Entrepreneurs, that engaged in high-tech business, predict the onset of the era of mini- and micro-production what could lead to decline market concentration. In particular, crowdsourcing is considered to be a promising area for the spread of competitive conditions today - an effective way of delegating tasks to the remote community of users via the Internet, which is seen as an environment and social tool for effective communication.

After all, without such prospects, the world economy risks becoming even more monopolized in the near future. For example, in the USA more than $75 \%$ of industry markets showed an increase in concentration levels, with the Herfindahl index increasing by more than $50 \%$. Also in the last two decades, the size of the average publicly listed company in the USA tripled in market capitalization: from $\$ 1.2$ billion at the beginning of the period to $\$ 3.7$ billion dollars in 2016. As explained this is the result of two tendencies: the reduction in the rate of establishment of new companies (from 14\% of existing firms in the late 1980s to less than $10 \%$ in 2014 ; a very high number of mergers, that for many years in this period have exceeded $\$ 2$ trillion in value per year [16, p. 120].

Conclusion. Various integration forms of monopolization process in a certain stage of economic development of mankind were initiationed to improve the efficiency of economic processes. The research paper has showed a correlation between the nascence of integration forms in the monopolization process with technological systems. Thus, we can single out the following factors that at certain stages associated with the processes of technological innovation, prompted businesses to merge and acquisition processes:

1. In the early stages of capitalism, the transition from factories, farms, small businesses to monopolistic associations was due to the threat of economic stagnation, the need to raising a big capital, as well as limited access to resources and the need to reduce average costs.

2. The next stage and more complex technological innovations, for market transformations and even greater industrial development required to overcome the investment deficit, to achieve the merger of financial and industrial capital, to overcome the inability of enterprises to independently organize the supply, production and marketing.

3. Informatization, computerization and globalization have led to the possibility of expanding production processes far beyond national economies and the mass monopolization of the world market through integration associations of companies around the world. 
4. Today, borders are even more blurred, workers are not reside to a specific place of work, management is remote, cooperation does not involve physical presence, and opportunities to implement new ideas are limited only by knowledge and skills. Competition based on enthusiasm and the desire to improve each other's welfare has great potential to reduce the influence of monopolistic integration groups.

\section{Список використаних джерел}

1. Господарський кодекс України від 16.01.2003 (у редакції закону від 01.01.2014) URL: https://zakon.rada.gov.ua/laws/show/436-15/ed20140101\#n220

2. Віскузі, В. Кіп. Економічна теорія регулювання та антимонопольна політика [Текст] : пер. з англ. В. К. Віскузі, Джон М. Вернон, Джозеф Е. Гарингтон - Київ: Видавництво Соломії Павличко «Основи», 2004. - $1047 \mathrm{c}$.

3. Данилейчук Р. Б. Основні напрями вдосконалення державного регулювання процесів інтеграції у галузі підприємництва. Державне регулювання економіки. № 1, 2010. - С. 220-224.

4. Корпорації та їх інтегровані структури: проблеми науки і практики: монографія. [Пономаренко В. С., Горбатов В. М., Кизим Н. А. та ін.]; за ред. В. С. Пономаренка. - 2007. - 344 с.

5. Леоненко П.М., Юхименко П.І. Економічна історія Навчальний посібник. Київ: Знання-Прес, 2004. - 499 с.

6. Промислова революція 4.0. На порозі нової епохи. 18 січня 2017 URL: htps://ua.korrespondent.net/business/web/3802445-promyslova-revoluitsiia-40-naporozi-novoi-epokhy

7. Транснаціональні корпорації та Україна. URL: http://www.geograf.com.ua/ geoinfocentre/20-human-geography-ukraineworld/266-tnk-and-ukraine

8. Федотова Ю.В. Інтегративні структури: етимологія, види і роль у забезпеченні економічного розвитку регіону. Глобальні та національні проблеми економіки. Випуск 15, 2017. - С. 414-419.

9. Федулова Л.І. Корпоративні структури в інноваційній діяльності: світовий досвід та можливості для України. Економіка і становлення нової системи господарювання. 2004. С. 9-27.

10. Яцкевич I. До питання про зміст поняття інтеграції суб’єктів підприємницької діяльності. Журнал європейської економіки. № 4, 2013. С. 473-483.

11. A Brief History of Transnational Corporations [Електронний ресурс] - Режим доступу: https://www.globalpolicy.org/empire/47068-a-brief-history-of-transnationalcorporations.html

12. Kordos M. Vojtovic S. (2016) Transnational Corporations in the Global World Economic Environment. Procedia - Social and Behavioral Sciences, 230, 150-158.

13. Ostroverkh P., Moryak T., Rudkovska, N. (2020) Metodolohichni aspekty otsinky rivnya monopolizatsiyi ekonomiky [Methodological aspects of assessing the level of monopolization of economy]. Efektyvna ekonomika, 8. Retrieved from: http://www.economy.nayka.com.ua/?op=1\&z=8099 [in Ukrainian].

14. Stephen R. (2017) John D. Rockefeller, Standard Oil, and the rise of corporate public relations in progressive America, 1902-1908. The Journal of the Gilded Age and Progressive Era, 3. Retrieved from: https://www.cambridge.org/core/journals/journalof-the-gilded-age-and-progressive-era

15. Zingales L. (2017) Towards a Political Theory of the Firm. Journal of Economic Perspectives, 3, 113-130. 


\section{References}

1. Hospodars'kyy kodeks Ukrayiny: Zakon Ukrayiny № 436-IV (u redaktsiyi zakonu vid 01.01.2014). [Commercial Code of Ukraine: Law of Ukraine № 436-IV (as amended by the law of January 1, 2014). Retrieved from: https://zakon.rada.gov.ua/laws/show/43615/ed20140101\#n220 [in Ukrainian].

2. Viskuzi, V. Kip. (2004). Ekonomichna teoriya rehulyuvannya ta antymonopol'na polityka [Economic theory of regulation and antitrust policy] Kyiv: Vydavnytstvo Solomiyi Pavlychko «Osnovy» [in Ukrainian].

3. Danyleychuk R. B. (2010) Osnovni napryamy vdoskonalennya derzhavnoho rehulyuvannya protsesiv intehratsiyi $u$ haluzi pidpryyemnytstva [The main directions of improving the state regulation of integration processes in the field of entrepreneurship]. State regulation of Economy, 1, 220-224 [in Ukrainian].

4. Korporatsiyi ta yikh intehrovani struktury: problemy nauky i praktyky: monohrafiya. [Ponomarenko V. S., Horbatov V. M., Kyzym N. A. ta in.]; za red. V. S. Ponomarenka (2007). [Corporations and their integrated structures: problems of science and practice: a monograph], [in Ukrainian].

5. Leonenko P.M., Yukhymenko P.I. (2004) Ekonomichna istoriya [Economic History] Textbook [in Ukrainian].

6. Promyslova revolyutsiya 4.0. Na porozi novoyi epokhy. [The Industrial Revolution 4.0. On the threshold of a new era]. Retrieved from: https://ua.korrespondent.net/business/web/3802445promyslova-revoluitsiia-40-na-porozi-novoi-epokhy [in Ukrainian].

7. Transnatsional'ni korporatsiyi ta Ukrayina [Transnational corporations and Ukraine]. Retrieved from: http://www.geograf.com.ua/geoinfocentre/20-human-geographyukraineworld/266-tnk-and-ukraine [in Ukrainian].

8. Fedotova Yu.V. (2017) Intehratyvni struktury: etymolohiya, vydy i rol' u zabezpechenni ekonomichnoho rozvytku rehionu. [Integrative structures: etymology, types and role in ensuring the economic development of the region]. Global and national economic problems, 15, 414-419 [in Ukrainian].

9. Fedulova L.I. (2004) Korporatyvni struktury v innovatsiyniy diyal'nosti: svitovyy dosvid ta mozhlyvosti dlya Ukrayiny [Corporate structures in innovation: world experience and opportunities for Ukraine]. Economy and the formation of a new management system, 9-27 [in Ukrainian].

10. Yatskevych I. (2013) Do pytannya pro zmist ponyattya intehratsiyi sub"yektiv pidpryyemnyts'koyi diyal'nosti [On the question of the content of the concept of integration of business entities]. Journal of European Economy, 4, 473-483 [in Ukrainian].

11. A Brief History of Transnational Corporations. Retrieved from: https://www.globalpolicy.org/ empire/47068-a-brief-history-of-transnational-corporations.html

12. Kordos M. Vojtovic S. (2016) Transnational Corporations in the Global World Economic Environment. Procedia - Social and Behavioral Sciences, 230, 150-158.

13. Ostroverkh P., Moryak T., Rudkovska, N. (2020) Metodolohichni aspekty otsinky rivnya monopolizatsiyi ekonomiky [Methodological aspects of assessing the level of monopolization of economy]. Efektyvna ekonomika, 8.

Retrieved from: http://www.economy.nayka.com.ua/?op=1\&z=8099 [in Ukrainian].

14. Stephen R. (2017) John D. Rockefeller, Standard Oil, and the rise of corporate public relations in progressive America, 1902-1908. The Journal of the Gilded Age and Progressive Era, 3. Retrieved from: https://www.cambridge.org/core/journals/journalof-the-gilded-age-and-progressive-era

15. Zingales L. (2017) Towards a Political Theory of the Firm. Journal of Economic Perspectives, 3, 113-130. 


\title{
ЕВОЛЮЦЙНІ ЕТАПИ РОЗВИТКУ ІНТЕГРАЦІЙНИХ ФОРМ МОНОПОЛІЗАЦІЙНОГО ПРОЦЕСУ
}

\author{
Наталія Рудковська
}

\author{
Львівський національний університет імені Івана Франка \\ 79008 м. Львів, проспект Свободи, 18 \\ e-mail:nataliya.rudkovska@lnu.edu.ua
}

\begin{abstract}
Анотація. Першочергове завдання економіки, як науки про раціональне розпорядження обмеженими ресурсами, не завжди виконується у сучасному глобалізованому світі. Людська ірраціональність та опортунізм змушують економічних суб'єктів винаходити що раз нові способи максимізації свого прибутку, що супроводжується погіршенням добробуту інших сторін. Поглиблення та загострення монополізаційних процесів, що відбувалося упродовж практично усіх періодів світового економічного розвитку, є закономірним наслідком цього прагнення. Захопити владу над обмеженими ресурсами задля реалізації контролю над ринком було так само звично у Середньовічній Європі на стихійних ярмарках, як сьогодні на ринку технологічної продукції. Проте, зважаючи на зростання можливостей масштабів впливу підприємців, що вийшли далеко за межі національних держав, процеси ринкових трансакцій потребують складніших ринкових структур. Позаяк саме технології та інновації зробили можливим той тип економічних систем, що ми спостерігаємо сьогодні у розвинутих економіках, то їх революційні зміни варто пов'язувати із еволюційними змінами ринкових інтеграційних форм при монополізаційних процесах.

Класичне трактування монополії як єдиного продавця на ринку, не заперечує можливості представлення іiі об'єднанням кількох чи навіть багатьох економічних суб'єктів, позбавлених економічної самостійності в результаті поглинання чи злиття, або ж які діють на ринку злагоджено. Монопольна влада на ринку означає, що виробничі ресурси не будуть використанні у раціональний спосіб, а потреби споживачів не будуть задоволенні повною мірою.

Важливість дослідження умов та чинників виникнення інтеграційних форм, що можуть сприяти монополізаційним процесам на галузевих ринках зумовила написання цієї статті. У роботі виокремлено етапи еволюції монополістичних об'єднань через взаємозв'язок із Технологічними революціями, як сприятливого середовища для їх розвитку.

Ключові слова: монополія, монополізація, інтеграційні форми монополізаційного процесу, трест, холдинг, ТНК.
\end{abstract}

